\title{
MATERNAL ATTITUDE, DIETARY INTAKE, AND NUTRITIONAL STATUS OF CHILDREN UNDER TWO YEARS OF AGE IN KLATEN, CENTRAL JAVA
}

\author{
Fatimah Sari'), Bhisma Murti'), Endang Sutisna3), Kusnandar4) \\ 1)Doctoral Program in Development Counseling, Graduates School, \\ Universitas Sebelas Maret \\ 2)Masters Program in Public Health, Universitas Sebelas Maret \\ 3) Department of Public Health, Faculty of Medicine, Universitas Sebelas Maret \\ 4) Graduate Studies in Agriculture, Universitas Sebelas Maret
}

\begin{abstract}
Background: Nutritional status of children is one of the major predictors of child survival. However, child malnutrition remains a major public health problem in most developing countries, including Indonesia. Child malnutrition includes underweight, stunting, wasting, and overweight/ obesity. This study aimed to analyze the associations of maternal attitude and dietary intake with nutritional status among children under two years of age in Klaten, Central Java.

Subjectsand Method: This was a cross sectional study conducted in Pandes Wedi Village, Klaten, Central Java. A sample of 30 children under 2 years of agewas selected for this study. The dependent variable was nutritional status of children. Nutritional status was measured in terms of weight for age Z-score. Children were classified as normal if they had $-2 \leq \mathrm{Z}$-score $<2$ and underweight if they had Z-score $<-2$. The independent variables were maternal attitude towards child nutrition and dietary intake. The dietary intake was measured in terms of recommended dietary allowance (RDA). The other data were collected by questionnaire. The data were analyzed by a logistic regression.

Results: Good nutritional status of children under 2 years of age was associated with positive maternal attitude $(\mathrm{OR}=2.34 ; 95 \% \mathrm{CI}=1.60$ to $7.20 ; \mathrm{p}=0.043)$ and adequate $\mathrm{RDA}(\mathrm{OR}=4.50 ; 95 \% \mathrm{CI}=2.17$ to $6.57 ; \mathrm{p}=0.011)$.

Conclusion: Good nutritional status of children under 2 years of age is associated with positive maternal attitude and adequate RDA.
\end{abstract}

Keywords: maternal attitude, food intake, recommended dietary allowance, nutritional status, children under 2 years of age

\section{Correspondence:}

Fatimah Sari. Doctoral Program in Development Counseling, Graduate School, Universitas Sebelas Maret, Jl. Ir. Sutami No.36A, Jebres, Surakarta, Central Java. Email: fatimahsari.gunabangsa@gmail.com. Mobile: 08126369026. 